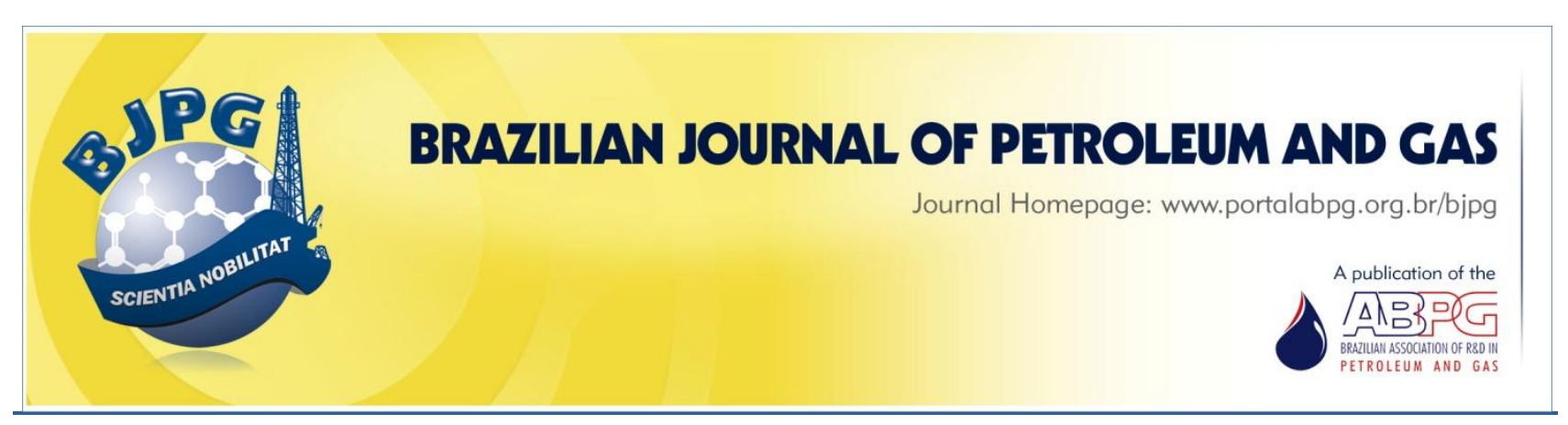

\title{
CEMENT SLURRIES OF OIL WELLS UNDER HIGH TEMPERATURE AND PRESSURE: THE EFFECTS OF THE USE OF CERAMIC WASTE AND SILICA FLOUR
}

\footnotetext{
${ }^{\text {a }}$ Souza, P. P. ${ }^{1}$; ${ }^{\text {a }}$ Soares, R. A.; ${ }^{\text {anjos, M. A.; }}{ }^{\text {}}$ Freitas, J. O.; ${ }^{\text {}}$ Martinelli, A. E.; ${ }^{\text {b }}$ Melo, D. F.

a Universidade Federal do Rio Grande do Norte, Cement Laboratory, Rio Grande do Norte, Brazil

b Universidade Federal do Rio Grande do Norte, Chemistry Institute, Rio Grande do Norte, Brazil

c Universidade Federal do Rio Grande do Norte, Department of Materials Engineering, Rio Grande do Norte, Brazil
}

\section{ABSTRACT}

This study evaluates the behavior of a ceramic waste material in partial and total substitution of a mineral additive, commonly used in oil well cement slurries, when exposed to high temperatures and pressures. The samples were submitted to a cycle of low temperature $\left(38^{\circ} \mathrm{C}\right)$ for 28 days, followed by exposure to $280^{\circ} \mathrm{C}$ and $6.5 \mathrm{MPa}$ (1000 psi) for 3 days. The evaluation was made by compression testing and $\mathrm{X}$-ray diffraction (XRD). The results showed that cement pastes containing ceramic waste, when combined with silica flour, produced hydrated products of low $\mathrm{Ca} / \mathrm{Si}$ ratios which maintained the compressive strength at satisfactory levels.

\section{KEYWORDS}

ceramic waste; silica flour; high temperature; high pressure; strength retrogression

\footnotetext{
${ }^{1}$ To whom all correspondence should be addressed. Address: Universidade Federal do Rio Grande do Norte, Instituto de Química, Laboratório de Cimentos, Campus Universitário Natal - Rio Grande do Norte - Brazil - CEP 59072-970 Telephone: +55 84 8718-2725 | E-mail:pdpsouza@hotmail.com doi:10.5419/bjpg2012-0009
} 


\section{INTRODUCTION}

Due to the high viscosity of heavy oils it is necessary to use special techniques to boost the oil from the reservoir and bring it to the surface. Among the techniques for recovering heavy oil, the methods that promote thermal heating of the reservoir receive special emphasis for its properties of reducing oil viscosity, thus facilitating its removal. Steam injection is one of the most used thermal recovering techniques because of its high technology, which yield high recovery factors (Queiroz et al., 2005).

However, when subjected to high temperatures and pressures, the physical and chemical behavior of Portland-based cement changes significantly. If the materials are not handled properly during the formulation stage, they can lose mechanical strength and increase permeability. These changes may lead to isolation loss and, consequently, provide a high risk to the continuation of activities (Griffith et al., 2004).

The calcium silicate hydrate ( $\mathrm{C}-\mathrm{S}-\mathrm{H})$ is the main phase, formed during the Portland cement hydration. It is the primary responsible for the mechanical strength of the hardened cement and the excellent physical and chemical stability at temperatures up to $110{ }^{\circ} \mathrm{C}$. At higher temperatures, there is a formation of high calcium/silicon $(\mathrm{Ca} / \mathrm{Si})$ ratio crystalline silicate hydrates, such as $\mathrm{C}_{3} \mathrm{~S}-\mathrm{H}_{1.5}\left(\mathrm{C}_{3} \mathrm{~S}\right.$ hydrate or Jaffeite) and $\mathrm{C}_{2} \mathrm{~S}-\mathrm{H}\left(\alpha-\mathrm{C}_{2} \mathrm{~S}\right.$ hydrate). These hydrates are deleterious to the mechanical properties of the resulting slurry (Jupe et al., 2007). This phenomenon is known as cement strength retrogression (Nelson, 1990).

Nevertheless, studies (Anjos et al., 2011; Eilers and Root, 1976; Herianto and Fathaddin, 2005; Rogers et al., 2006) show that cement strength retrogression can be avoided by adding $30-40 \%$ of silica based-materials to the mixture. This quantity of silica is sufficient to consume large amounts of calcium hydroxide and reduce the $\mathrm{Ca} / \mathrm{Si}$ ratio of $\mathrm{C}$ $\mathrm{S}-\mathrm{H}$ phases from 1.5 to 1.0. In the presence of silica and at a temperature of about $110{ }^{\circ} \mathrm{C}$, a phase known as Tobermorite is formed in lieu of the high $\mathrm{Ca} / \mathrm{Si}$ ratio phases, preserving the mixture's mechanical strength and permeability properties. Increasing the temperature to about $150{ }^{\circ} \mathrm{C}$, Tobermorite usually produces Xonotlite and a smaller amount of Gyrolite, promoting little changes in cement strength (Nelson, 1990).

The silica used as a mineral additive in cementitious products can be originated from several sources such as microsilica, also called or silica fume, a very finely spheres of non-crystalline silica, a byproduct of electric furnaces used for obtaining silicon and silicon alloys (Taylor, 1990); fly ashes, ashes separated from the flue gas of a power station burning pulverized coal with the chemical composition depending on the minerals associated with the coal (Taylor, 1990); metakaolin, a high reactivity metastable phase originated from the calcination of the mineral kaolinite at $700-800{ }^{\circ} \mathrm{C}$ used as a pozzolanic material (Shvarzman et al., 2003). There are also many researches indicating the possibility of using other sources of silica for cement-based products such as rice husk ash (Jauberthie et al., 2000), sugar cane biomass ash (Aigbodion et al., 2010), ceramic roof tile wastes (Lavat et al., 2009), natural zeolite tuffs (Snellings et al., 2010) and cracking catalyst fluid (Paya et al., 2003).

Currently, the only material used to prevent or reduce harmful reactions caused by high temperatures is silica flour, a commercial additive made of finely divided $\mathrm{SiO}_{2}$. The use of alternative sources of silica in place of commercial additives proves to be very attractive from both economic and environmental standpoints. From an economic point of view, these materials have low added value, which would reduce production costs. From an as the environmental perspective it would be able of promoting the recovery and recycling of waste material, representing the most attractive solution for problems of treatment and final disposal (Menezes et al., 2009). This study evaluated the effects of the use of silica flour and a ceramic waste in the chemical and physical behaviors of cement slurries subjected to high temperatures and pressures.

\section{EXPERIMENTAL PROCEDURES}

\subsection{Materials}

The cement slurries were produced using a Portland cement with similar proprieties to the class $\mathrm{G}$ cement used in oil-well's cementation. The ceramic waste used was generated during a surface 
Table 1. Chemical composition of the mineral additives (Wt.\%).

\begin{tabular}{ccc}
\hline Composition & Silica flour & Ceramic Waste \\
\hline $\mathrm{SiO}_{2}$ & 95.70 & 62.01 \\
$\mathrm{Al}_{2} \mathrm{O}_{3}$ & 2.00 & 21.77 \\
$\mathrm{Fe}_{2} \mathrm{O}_{3}$ & 0.20 & 0.75 \\
$\mathrm{CaO}$ & - & 1.18 \\
$\mathrm{MgO}$ & - & 7.16 \\
$\mathrm{SO}$ & 1.80 & 2.12 \\
$\mathrm{Na}_{3} \mathrm{O}$ & - & - \\
$\mathrm{K}_{2} \mathrm{O}$ & - & 4.07 \\
\hline
\end{tabular}

polishing process. This process provides desirable properties such as waterproofness, cleanability, stain resistance, mechanical strength and abrasion resistance to a certain class of ceramic tile, along with an improved aesthetic appeal (Kummer et al., 2007). During this process, the ceramic's body is reduced up to $90 \%$ of its original mass (Wiggers et al., 2007). A single Brazilian company is responsible for about 30 tons of waste daily, which is disposed entirely in landfills (Souza, 2007). The product produced is incorporated into the water to assist in the polishing process. Subsequently, the residue is submitted to a physiochemical treatment for its removal, and the treated water returns to the process. The waste will remain in the storage yard until reaching its final destination (Souza, 2007). The material used in the study was collected from a storage yard.

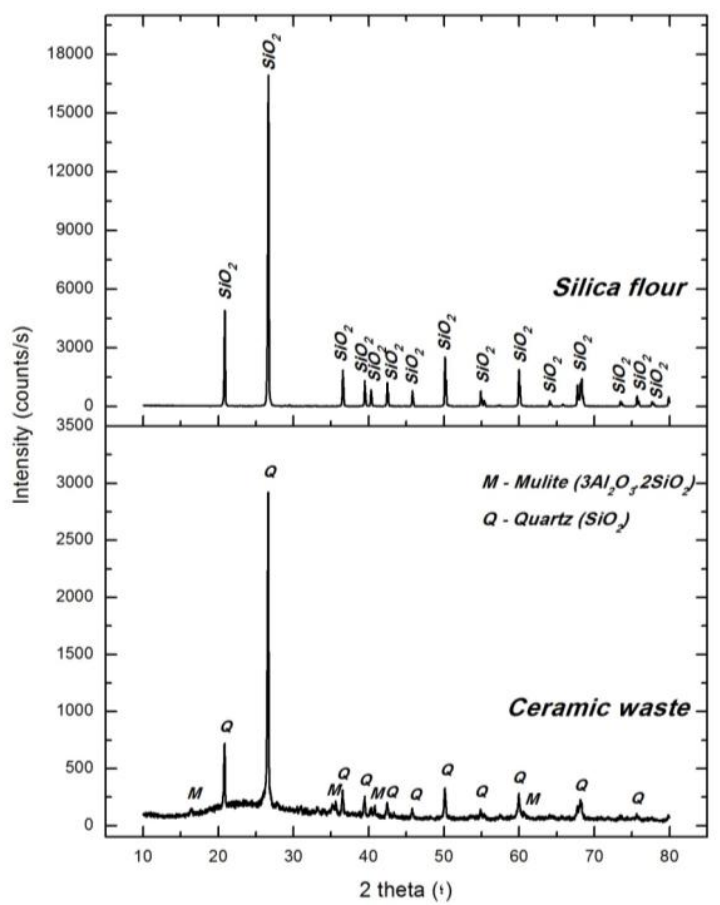

Figure 1. XRD of silica flour and the ceramic waste.
The silica flour selected is a commercial product commonly used for cementing operations in hightemperature oil wells. The chemical properties of those materials were determined or estimated by energy-dispersive X-ray fluorescence (XRF) as shown in Table 1.

The high concentration of silicon in the ceramic waste, $62.01 \%$, is essential for such application, since to form low $\mathrm{Ca} / \mathrm{Si}$ ratio phases in the cement it is necessary to add materials with high concentration of this element. A high concentration of aluminum, $21.77 \%$, can lead to additional improvements. The conversion of Tobermorite into Xonotlite that occurs around $150^{\circ} \mathrm{C}$ in cement slurries with silica-based materials can create shrinkage and cracks in the hardened cement, resulting in unsafe operation. However, the presence of some aluminum atoms can replace others of silicon in that phase, causing an insignificant amount of shrinkage in the hardened paste (Jupe et al., 2007).

The characterization of the phases presented by the mineral additives is shown in Fig. 1. The figures were fixed using the X-ray diffraction technique, having CuK $\alpha$ as the radiation source, with voltage of $30 \mathrm{kV}$ and current of $30 \mathrm{~mA}$. The data were collected in the goniometer velocity of $0.02^{\circ} 2 \theta$ degree by step with counting time of 1.0 second by step, from 10 to $80^{\circ} 2 \theta$ degrees. The XRD analysis revealed that the ceramic waste consisted in its higher proportion of silica in the form of quartz, and small amounts of mullite. The peaks are similar to those of silica flour, but with lower intensities, which represent a lower degree of crystallinity of the waste over silica flour.

The particle size distribution of the ceramic waste and the silica flour (Figure 2) was fixed trough a laser granulometer in liquid environment. 


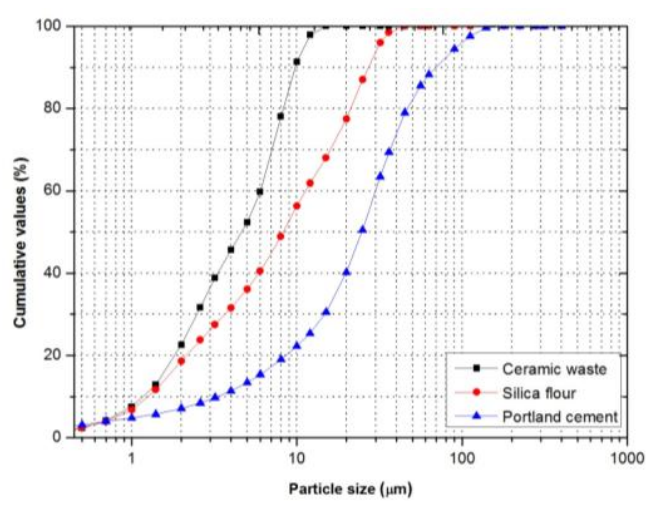

Figure 2. Particle size distribution curves of cement and mineral additives.

The ceramic waste was the one with the lowest average particle size, $5.13 \mu \mathrm{m}$, against $24.73 \mu \mathrm{m}$ from the cement and $8.26 \mu \mathrm{m}$ from the silica flour. The particle size distribution is a good feature because the smaller the particle size of the mineral additive, the greater will be the area available for reactions. Also, mineral additive particles do not react chemically and can fill existing gaps, reducing the porosity and permeability, thus increasing the compressive strength of cement paste (Mehta and Monteiro, 1994).

\subsection{Cement slurries formulation}

To determine the mass of the components of a given oil well cement slurry, initially, the specific weight or water/cement ratio and concentration of additives solid and liquid are fixed. Then, the mass of the components is determined. The calculations of the components mass were made according to the recommendations of the API RP 10 practices (American Petroleum Institute, 2000-b).
The study evaluated formulations containing only ceramic waste $(\mathrm{CW})$ and others containing blends of ceramic waste and silica flour (SF) in different concentrations. The slurries specific weights were fixed at $1.87 \mathrm{~g} / \mathrm{cm}^{3}$, because it is the most used specific weight in cementing operations with special Portland cement (SPC). For comparative purposes it was used a formulation containing cement and water (RFNC), and another with $40 \%$ silica flour (40SF), because this is the usual concentration used for cementing operations in high temperature oil wells. The Table 2 presents the components' concentrations and their respective masses for each formulation adopted.

The cement-slurry mixtures were carried out in a mixer in accordance with API SPEC 10 (American Petroleum Institute, 2000-a). The experiment molded cubic test-samples with edges of $5.0 \mathrm{~cm}$. The samples were submitted to a hydrating process (cure) in a thermal bath at $38^{\circ} \mathrm{C}$ for 28 days. This temperature was chosen to be near to downhole temperatures of oil wells that use the steam injection technique for oil recovery. This technique is used in wells up to $800 \mathrm{~m}$ depth, approximately, because to greater depths the injected steam loses effectiveness.

After this step, a sample of each formulation was collected for compressive testing. Others samples were placed in a pressurized chamber and subjected to 3 additional days of cure under high temperature $\left(280^{\circ} \mathrm{C}\right)$ and pressure $(6.5 \mathrm{MPa})$. Then, the samples were tested mechanically. All samples were also analyzed by $\mathrm{X}$-ray diffraction using CuK $\alpha$ radiation, a voltage of $30 \mathrm{kV}$, and a current of 30 $\mathrm{mA}$. The data collected from 10 to $60^{\circ} 2 \theta$ degrees.

Table 2. Components concentrations and masses.

\begin{tabular}{|c|c|c|c|c|c|c|c|}
\hline \multirow{2}{*}{ Formulation } & \multicolumn{2}{|c|}{ Content (\%) } & \multicolumn{4}{|c|}{ Composition (g) } & \multirow{2}{*}{$\begin{array}{c}\text { Water/cement } \\
\text { factor }(\mathrm{W} / \mathrm{C})\end{array}$} \\
\hline & CW & SF & SPC & Water & CW & SF & \\
\hline RFNC & --- & --- & 765.75 & 353.16 & --- & --- & 0.46 \\
\hline $40 S F$ & --- & 40 & 560.24 & 337.24 & --- & 224.10 & 0.60 \\
\hline $10 \mathrm{CW}$ & 10 & --- & 705.11 & 343.23 & 70.51 & --- & 0.49 \\
\hline $20 \mathrm{CW}$ & 20 & --- & 653.69 & 334.63 & 130.74 & --- & 0.51 \\
\hline $30 \mathrm{CW}$ & 30 & --- & 609.25 & 327.19 & 182.78 & --- & 0.54 \\
\hline $20 C W-30 S F$ & 20 & 30 & 529.10 & 322.77 & 105.82 & 158.73 & 0.61 \\
\hline $25 C W-25 S F$ & 25 & 25 & 530.35 & 320.52 & 132.59 & 132.59 & 0.60 \\
\hline $30 \mathrm{CW}-20 \mathrm{SF}$ & 30 & 20 & 531.36 & 318.86 & 159.41 & 106.27 & 0.60 \\
\hline
\end{tabular}

*CW - Ceramic Waste; SF - Silica Flour; SPC - Especial Portland Cement 


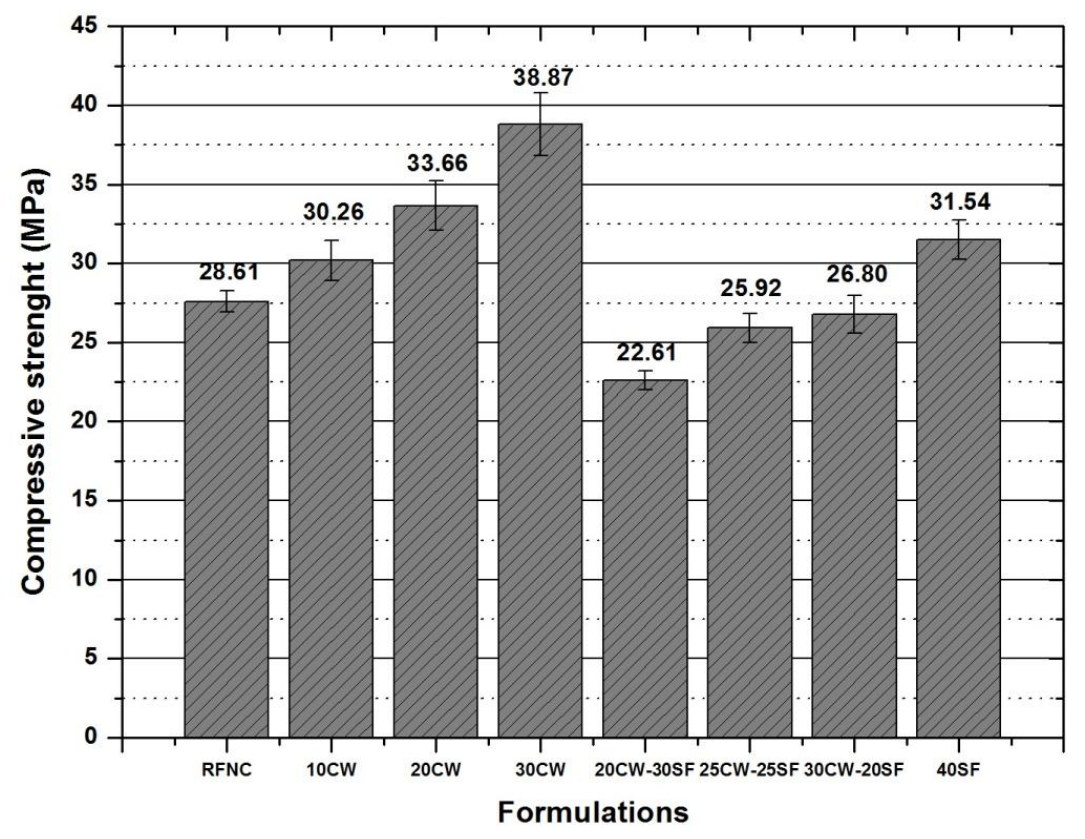

Figure 3. Compressive strength -28 days, $38{ }^{\circ} \mathrm{C}$.

\section{RESULTS AND DISCUSSION}

Initially, it was verified the influence of the ceramic waste and the silica flour in the samples just subjected to the simple cure $\left(38^{\circ} \mathrm{C}\right.$ for 28 days) to serve as reference for subsequent comparison with patterns of those undergoing high temperatures and pressures. Figure 3 shows the mechanical properties of those samples. The cement slurries that contained only ceramic waste presented compressive strength directly proportional to its concentration. The formulation containing silica flour (40SF) also presented a little increase in compressive strength. The blended samples, ceramic waste and silica flour, showed slight reductions when compared with the reference formulation.

The X-ray diffractogram displayed in Figure 4 shows the reference slurry is formed by calcium hydroxide (Portlandite), a calcium silicate hydrate, Ettringite, and a calcium silica-aluminate hydrate known as Gismondine. The formulations containing ceramic waste, silica flour, and the blends of both presented similar hydration products to the reference sample. Differently, these formulations had peaks of crystalline silica that did not react, as can be seen mainly in the peaks located at 20.91 and $26.60^{\circ}$. This result was expected considering that the addition used is rich in that phase. Moreover, the Portlandite peaks (mainly 18.04,
34.10 , and $47.122 \theta$ degrees) of all slurries with any addition had lower intensities than those of the reference slurry. This reduction confirms the existence of a pozzolanic reaction between calcium hydroxide $\left(\mathrm{Ca}(\mathrm{OH})_{2}\right)$, formed during hydration of $\mathrm{C}_{3} \mathrm{~S}$ and $\mathrm{C}_{2} \mathrm{~S}$ phases of Portland cement and the addition rich in silica.

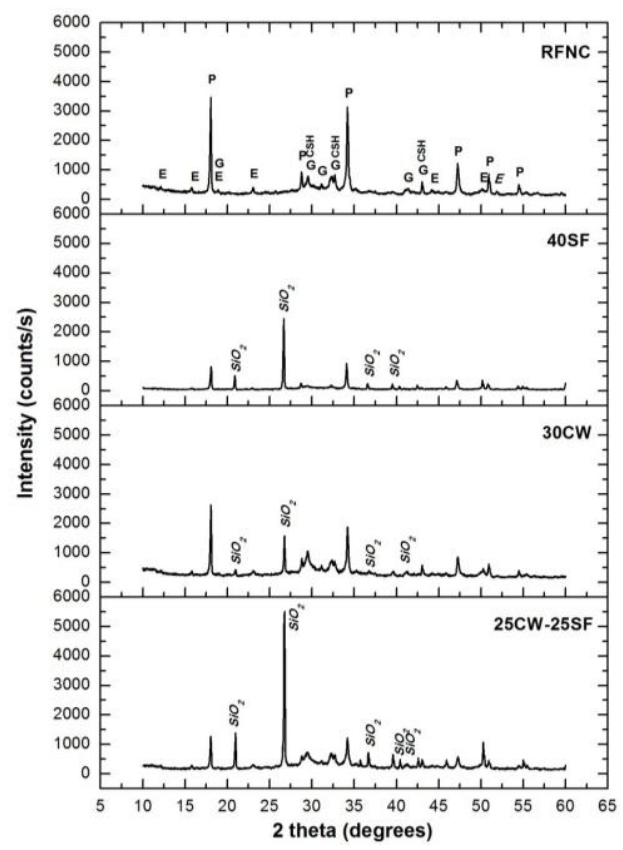

Figure 4. XRD spectra: samples cured at 28 days, $30^{\circ} \mathrm{C}$. Where: $\mathrm{P}$ - Portlandite $\mathrm{Ca}(\mathrm{OH})_{2}$; E- Ettringite $\mathrm{Ca}_{6} \cdot \mathrm{Al}_{2} \cdot \mathrm{SO}_{4} \cdot 3(\mathrm{OH})_{12} \cdot 26 \mathrm{H}_{2} \mathrm{O} ; \mathrm{G}$ - Gismondine Ca. $\mathrm{Al}_{2} \cdot \mathrm{Si}_{2} \cdot \mathrm{O}_{8} \cdot 4 \mathrm{H}_{2} \mathrm{O} ; \mathrm{CSH}-\mathrm{Ca}_{1.5} \cdot \mathrm{SiO}_{3.5} \cdot \mathrm{xH}_{2} \mathrm{O} ; \mathrm{SiO}_{2}-$ Silica. 


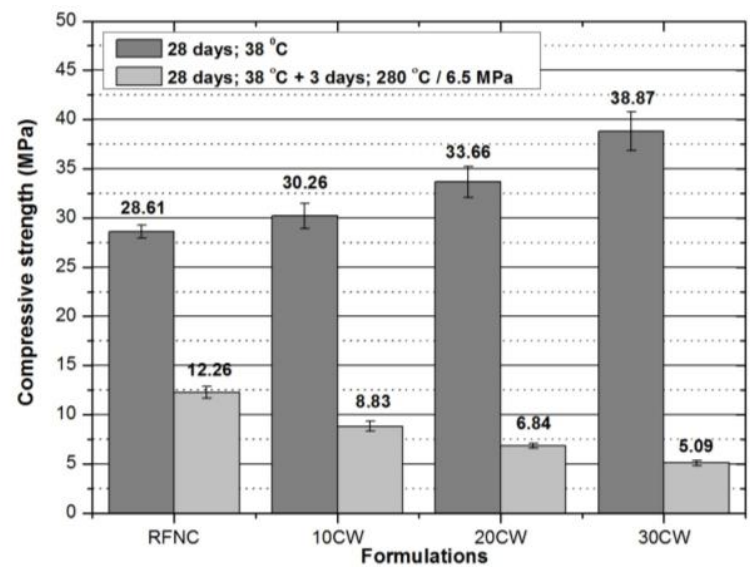

Figure 5. Compressive strength comparison between the samples just cured $\left(28\right.$ days at $\left.38^{\circ} \mathrm{C}\right)$ and those subjected to the steam injection simulation ( 28 days at $38^{\circ} \mathrm{C}+3$ days at $280^{\circ} \mathrm{C}$ and $6.5 \mathrm{MPa}$ ) - reference sample and ceramic waste-doped samples.

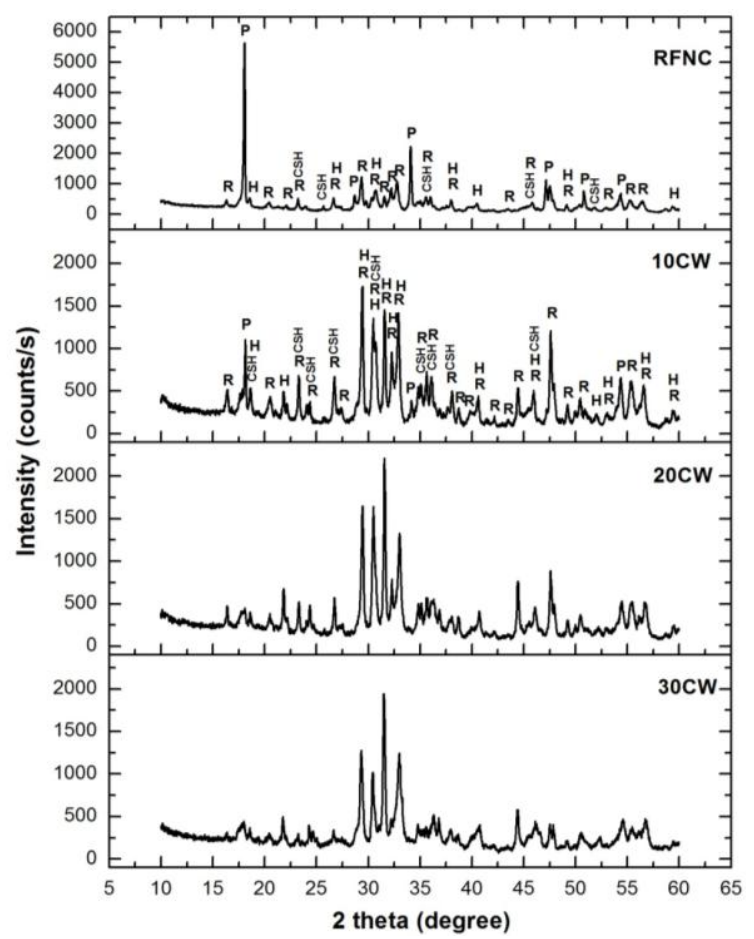

Figure 6. XRD spectra: samples cured for 28 days at $38^{\circ} \mathrm{C}+3$ days at $280^{\circ} \mathrm{C}$ and $6.5 \mathrm{MPa}$. Where: $\mathrm{P}$ -

Portlandite $\mathrm{Ca}(\mathrm{OH})_{2}$; R- Reinhardbraunsite $\mathrm{Ca}_{5} \cdot\left(\mathrm{SiO}_{4}\right)_{2} \cdot(\mathrm{OH})_{2}, \mathrm{H}$ - Hillebrandite $\mathrm{Ca}_{2} \cdot\left(\mathrm{SiO}_{3}\right) \cdot(\mathrm{OH})_{2}$ and $\mathrm{CSH}-\mathrm{Ca}_{2} \cdot \mathrm{SiO}_{4} \cdot \mathrm{H}_{2} \mathrm{O}$.

The Figures 5 and 7 compare the compressive strength among the samples cured and those subjected to the steam injection simulation. The Figure 5 compares the reference paste with the ones with addition of just ceramic waste. The

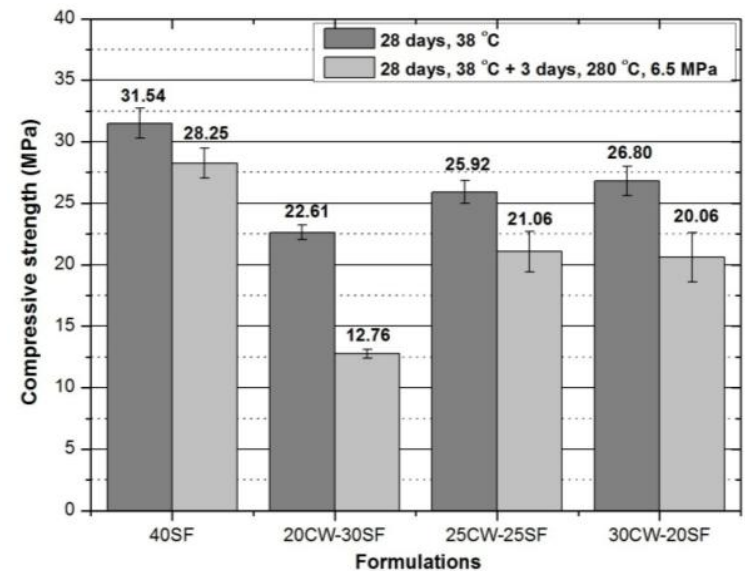

Figure 7. Compressive strength comparison between the samples just cured ( 28 days at $38^{\circ} \mathrm{C}$ ) and those subjected to the steam injection simulation $\left(28\right.$ days at $38^{\circ} \mathrm{C}+3$ days at $280^{\circ} \mathrm{C}$ and $6.5 \mathrm{MPa}$ ) - silica flour-doped sample and blendsdoped samples.

results show that all formulations suffered strength retrogression after subjected to the high temperature cycle. The pastes presented strength loss directly proportional to the amount of waste added, reaching a loss of more than $85 \%$ for the one containing $30 \%$ of addition, resulting in a compressive strength of only $6.84 \mathrm{MPa}$.

Formation conditions and stability of the hydrated calcium silicates in cement pastes submitted to high temperatures and pressures are highly relevant to determining strength and durability. The presence of large amounts of Portlandite (calcium hydroxide) and calcium silicate hydrate phases with higher than $1 \mathrm{Ca} / \mathrm{Si}$ ratio in hydrated pastes are considered deleterious because they lead to high permeability and low compressive strength (Luke, 2004). The elevated strength reduction of the reference slurry and of those with addition of ceramic waste can be explained by their X-ray diffractogram (Figure 6). The reference sample diffractogram shows that the phases formed after the initial cure were replaced by the phases Reinhardbraunsite $\left(\mathrm{Ca}_{5} \cdot\left(\mathrm{SiO}_{4}\right)_{2} \cdot(\mathrm{OH})_{2}\right)$, Hillebrandite $\left(\mathrm{Ca}_{2} \cdot\left(\mathrm{SiO}_{3}\right) \cdot(\mathrm{OH})_{2}\right)$, and a sort of $\mathrm{CSH}\left(\mathrm{Ca}_{2} \cdot \mathrm{SiO}_{4} \cdot \mathrm{H}_{2} \mathrm{O}\right)$, which have $\mathrm{Ca} / \mathrm{Si}$ ratios of 2.5, 2.0 and 2.0, respectively. The $10 \mathrm{CW}$, $20 \mathrm{CW}$, and $30 \mathrm{CW}$ samples presented the same hydration products as the reference.

The additive used was formed by over $60 \%$ of silicon and, unexpectedly, the experiment did not observe the formation of any hydrated phase with 


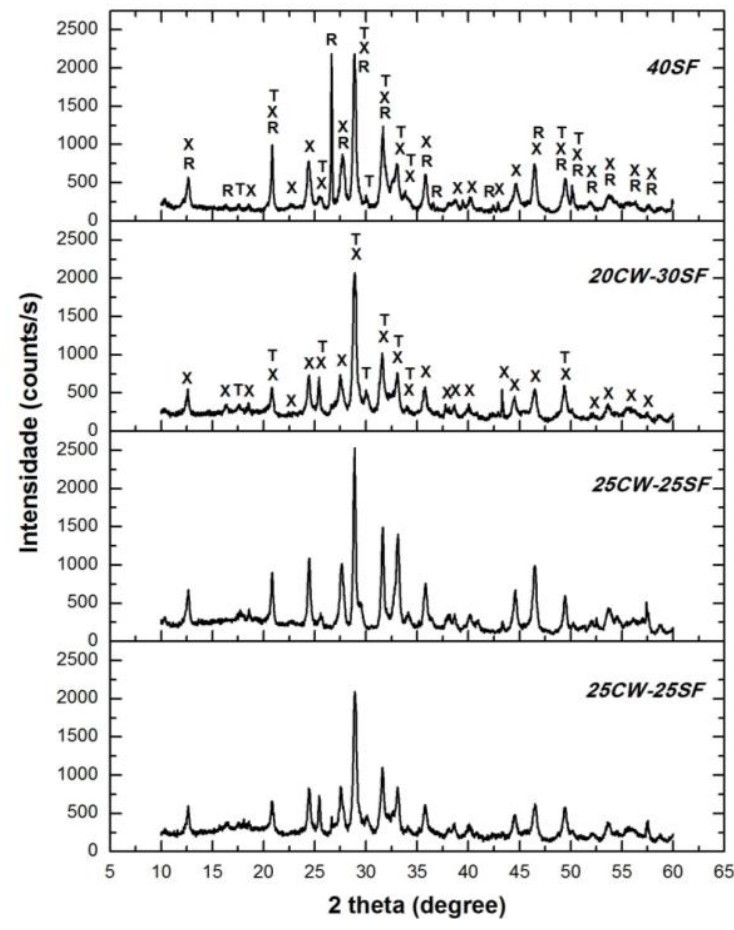

Figure 8. XRD spectra: samples cured for 28 days at $38^{\circ} \mathrm{C}+3$ days at $280^{\circ} \mathrm{C}$ and $6.5 \mathrm{MPa}$. Where: $\mathrm{X}$ Xonotlite $-\mathrm{Ca}_{6} \cdot \mathrm{Si}_{6} \cdot \mathrm{O}_{17} \cdot(\mathrm{OH})_{2} ; \mathrm{T}$ - Tobermorite $\mathrm{Ca}_{5} \cdot \mathrm{Si}_{6} \cdot(\mathrm{O}, \mathrm{OH}, \mathrm{F})_{18} \cdot 5 \mathrm{H}_{2} \mathrm{O}$ and $\mathrm{R}$ - Rosenhahnite $\mathrm{Ca}_{3} \cdot\left(\mathrm{Si}_{3} \mathrm{O}_{8} \cdot(\mathrm{OH})_{2}\right.$.

$\mathrm{Ca} / \mathrm{Si}$ ratios equal to or lesser than 1.0 in any cement paste with addition of ceramic waste. Thus, the elevated $\mathrm{Ca} / \mathrm{Si}$ ratio of the hydrated products formed is responsible for the drastic reduction in compressive strength observed after the steam injection simulation.

Moreover, all blended pastes, ceramic waste and silica flour, showed low strength loss (Figure 7). Particularly, 25CW-25SF and 30CW-20SF suffered losses of 18.75 and $25.12 \%$, causing the compressive strength to remain at 21.06 and 20.06MPa, respectively. These values were superior to the sample containing $40 \%$ silica flour, which had a loss of $10.32 \%$ after the simulation, maintaining its strength at $28.25 \mathrm{MPa}$.

Cement pastes used in oil wells need to present a compressive strength of at least $17 \mathrm{MPa}$. Such strength levels can bear the mechanical stresses generated in the wells. Therefore, based solely on the compressive strength, it is possible to classify the samples $25 \mathrm{CW}-25 \mathrm{SF}$ and $30 \mathrm{CW}-20 \mathrm{SF}$ with having potential for use in oil wells subjected to thermal recovery by steam injection (Smith, 1980).
The XRD spectra of the 40SF and the blended samples are shown in Figure 8 . The 40SF slurry is formed by the phases Xonotlite $\left(\mathrm{Ca}_{6} \cdot \mathrm{Si}_{6} \cdot \mathrm{O}_{17} \cdot(\mathrm{OH})_{2}\right)$, Rosenhahnite $\left(\mathrm{Ca}_{3} \cdot\left(\mathrm{Si}_{3} \mathrm{O}_{8} \cdot(\mathrm{OH})_{2}\right)\right)$, and Tobermorite $\left(\mathrm{Ca}_{5} \cdot \mathrm{Si}_{6} \cdot(\mathrm{O}, \mathrm{OH}, \mathrm{F})_{18} .5 \mathrm{H}_{2} \mathrm{O}\right)$, which exhibit $\mathrm{Ca} / \mathrm{Si}$ ratio of 1.0, 1.0, and 0.83 , respectively. At last, the Portlandite phase was totally consumed.

Similarly, the Portlandite of the blended slurries was consumed. The blended slurries presented only the phases Xonotlite and Tobermorite. The complete consumption of Portlandite phase and the formation of silica-rich phases are responsible for maintaining the compressive strength of those pastes at high levels. When the anhydrous mixture presents relations $\mathrm{CaO} / \mathrm{SiO}_{2}$ and $\mathrm{CaO} /\left(\mathrm{SiO}+\mathrm{Al}_{2} \mathrm{O}_{3}\right)$ equal to or lower than 1 , and the hydrating temperature is higher than $110^{\circ} \mathrm{C}$, there is the conversion of hydrate calcium silicate (little crystalline $\mathrm{C}-\mathrm{S}-\mathrm{H})$ to silica-rich phases as hydrate calcium silicates, like Xonotlite and Tobermorite. These hydrate products are responsible for the maintenance of compressive strength in acceptable levels (Anjos et al., 2010).

\section{CONCLUSIONS}

The ceramic waste presented characteristics of the pozzolanic material used in the characterization by X-ray diffraction. The samples containing incremental additions of the additive, cured at $38^{\circ} \mathrm{C}$ for 28 days, exhibited a consumption of calcium hydroxide in the presence of the additive. The waste's reactivity was confirmed through compressive testing of the samples, which showed that compressive strength is directly proportional to the presence of waste.

All formulations suffered strength retrogression after the steam injection simulation, if compared to the post initial cure strength. The formulations with the addition of ceramic waste presented the greatest losses, reaching $85 \%$, phenomenon that was justified by the presence of $\mathrm{C}-\mathrm{S}-\mathrm{H}$ phases with $\mathrm{Ca} / \mathrm{Si}$ ratios equal to or greater than 2.0. However, the formulations $25 \mathrm{CW}-25 \mathrm{SF}$ and $30 \mathrm{CW}-20 \mathrm{SF}$, as well as the cement slurry containing $40 \%$ silica flour, maintained the strength at satisfactory levels (above 17MPa). This was justified mainly by the total consumption of Portlandite and the presence of phases with $\mathrm{Ca} / \mathrm{Si}$ ratios equal to or smaller than 1.0 . 
Through the experiments, it was possible to conclude that the use of the ceramic waste isolated is not enough to prevent the strength retrogression of cement pastes used in oil wells subjected to steam injection. However, when this product was added to partial replacement of silica flour, in certain proportions, were obtained satisfactory results. The formulations developed present a reduction of just over $5 \%$ of cement mass, while the reduction of silica flour reached $52 \%$ in mass, when compared with the slurry containing $40 \%$ of silica flour, the most common formulation used for cementing operations of wells subjected to high temperatures.

\section{REFERENCES}

Aigbodion, V. S.; Hassan, S. B.; Ause, T.; Nyior, G. B. Potential utilization of solid waste (bagasse ash). Journal of Minerals \& Materials Characterization \& Engineering, v. 9(1), p.67-77, 2010.

American Petroleum Institute. API SPEC 10: API SPEC $10 B$ - Recommended practice for testing well cement, 2000(b).

American Petroleum Institute. API SPEC 10: API SPEC 10A - Specifications for cements and materials for well cementing, 2000(a).

Anjos, M. A. S.; Renovato, T.; Souza, P.; Melo, D.; Melo, M.; Freitas, J. Cement slurry with silica flour and metakaolin for cementation of oil-wells subject to high temperature. Journal of Materials Science and Engineering, v. 4(12), 2010.

Anjos, M. A. S.; Martinelli, A. E.; Melo, D. M. A. Effect of sugarcane biomass waste in cement slurries submitted to high temperature and pressure. Materials Science and Engineering A, v.529, p. 49-54, 2011.

http://dx.doi.org/10.1016/i.msea.2011.08.056

Eilers, L. H.; Root, R. L. Long-term effects of high temperature on strength retrogression of cements. In: Proceedings of the Annual California Regional Meeting of the Society of Petroleum Engineers of AIME, Long Beach, California, 1976.
Griffith, J. E.; Lende, G.; Ravi, K.; Saasen, A.; Jordal, O. H. Foam cement engineering and implementation for cement sheath integrity at high temperature and pressure. In: IADC/SPE Drilling Conference, Texas, 2004.

Herianto; Fathaddin, M. T. Effects of additives and conditioning time on compressive and shear bond strengths of geothermal well cement. Proceedings World Geothermal Congress. Antalya, Turkey, 2005.

Jauberthie, R.; Rendell, F.; Tamba, S.; Cisse, I. Origin of the pozzolanic effect of rice husks. Construction and Building Materials, v. 14, p.419423, 2000.

http://dx.doi.org/10.1016/S0950-0618(00)00045-3

Jupe, A. C.; Wilkinson, A. P.; Luke, K.; Funkhouser, G. P. Class H cement hydration at 180 ${ }^{\circ} \mathrm{C}$ and high pressure in the presence of added silica. Cement and Concrete Research, v.38, p. 660666, 2007.

http://dx.doi.org/10.1016/i.cemconres.2007.12.004

Kummer, L.; Bassetti, F. J.; Hiella, H. G., Azevedo, J. C. R. Reutilização dos resíduos de polimento de porcelanato e feldspato na fabricação de novo produto cerâmico. Cerâmica Industrial, v.12(3), p.34-38, 2007. (In Portuguese)

Lavat, A. E.; Trezza, M. A.; Poggi, M. Characterization of ceramic roof tile wastes as pozzolanic admixture. Waste Management, v.29, p.1666-1674, 2009.

http://dx.doi.org/10.1016/i.wasman.2008.10.019

Luke, K. Phase studies of pozzolanic stabilized calcium silicate hydrates at $180^{\circ} \mathrm{C}$. Cement and Concrete Research, p.1725-1732, 2004. http://dx.doi.org/10.1016/i.cemconres.2004.05.021

Mehta, P. K.; Monteiro, P. J. M. Concreto: estrutura, propriedades e materiais. São Paulo: Pini, 1994. (In Portuguese)

Menezes, R. R.; Neves, G. A.; Souza, J.; Melo, W. A.; Ferreira, H. S.; Ferreira, H. C. Atividade pozolânica dos resíduos do beneficiamento do caulim para uso em argamassas para alvenaria. Revista Brasileira de Engenharia Agrícola e Ambiental, v.13(6), p.795-801, 2009. (In Portuguese) 
Nelson, E. B. Well Cementing. Sugar Land. Texas: Dowell Schlumberger Educational Service, 1990.

Paya, J.; Monzó, J.; Borrachero, M. V.; Velázquez, S.; Bonilla, M. Determination of the pozzolanic activity of fluid catalytic cracking residue. Thermogravimetric analysis studies on FC3R-lime pastes. Cement and Concrete Research, v.3, p.1085-1091, 2003.

http://dx.doi.org/10.1590/S1415-43662009000600019

Queiroz, G. O.; Barillas, J. L. M.; Dutra Jr., T. V.; Mata, W.; Barros Neto, E. L. Influência da cota de vapor no processo de injeção cíclica de vapor. In: 3o Congresso Brasileiro de P\&D em Petróleo e Gás, Salvador, 2005. (In Portuguese)

Rogers, M. J.; Dillenbeck, R. L.; Bray, W. S. Use of non-API cements for critical oilwell applications. In: IADC/SPE Asia Drilling Technology Conference And Exhibition, Thailand, 2006.

Shvarzman, A.; Kovler, K.; Grader, G. S.; Shter, G. E. The effect of dehydroxylaton/amorphization degree on pozzolanic activity of kaolinite. Cement and Concrete Research, v. 33, p.405-416, 2003. http://dx.doi.org/10.1016/S0008-8846(02)00975-4
Smith, D. K. Silica flour - Mechanism for improving cementing composition for hightemperature well conditions. Petroleum Engineer International 52 (1980) 43-48.

Snellings, R.; Mertens, G.; Elsen, J. Calorimetric evolution of the early pozzolanic reaction of natural zeolites. Journal of Thermal Analysis Calorimetry, v.101, p.97-105, 2010. http://dx.doi.org/10.1007/s10973-009-0449-x

Souza, P. A. B. F. Estudo do comportamento plástico, mecânico, microestrutural e térmico do concreto produzido com resíduo de porcelanato. 232f. Tese de Doutorado. Programa de PósGraduação em Ciências e Engenharia de Materiais, Universidade Federal do Rio Grande do Norte, Natal, Brazil, 2007. (In Portuguese)

Taylor, H. F. W. Cement Chemistry. London: Academic Press, 1990.

Wiggers, W. S.; Santos, R. A.; Hotza, D. Evolução da Superfície do Porcelanato ao Longo do Processo de Polimento. Cerâmica Industrial, v.12(1-2), p.2730, 2007. (In Portuguese) 